\title{
Ideas for a Regulatory Definition of FinTech
}

\author{
Submitted 14/12/19, $1^{\text {st }}$ revision 09/02/20, $2^{\text {nd }}$ revision 15/03/20, accepted 02/04/20
}

\begin{abstract}
Ramona Rupeika-Apoga ${ }^{1}$, Eleftherios I. Thalassinos ${ }^{2}$
Abstract:

Purpose: The aim of the paper is to develop the approach to a legal definition of FinTech. Design/Methodology/Approach: In this paper we evolve possible approaches of FinTech legal definition, investigate existing approaches at the international level and examine the policies applied at the national levels. Document analysis, as a form of qualitative research, was used in this study.

Findings: We found that in most countries the legislation does not specifically address fintech companies, and the legal framework equally regulates the activities of traditional service providers and fintech operators. In our opinion, no specific legislation for FinTech companies needed, each type of activity provided by a financial or technology company is subject to a specific legislation/regulation with primary focus on services and products provided as payments, insurance, investments etc.
\end{abstract}

Practical Implications: The term FinTech is freely used by policy makers, regulators, companies, researchers, academics and the public, both nationally and internationally. According to international organizations such as the IMF, the World Bank and the OECD, FinTech offers the opportunity to accelerate economic growth and expand financial affordability/inclusion in all countries. Some countries are increasingly striving to become global or international regional hubs for FinTech and are working hard to develop interagency government strategies with a supportive legal environment.

Originality/Value: There is still confusion about the nature and dynamics of FinTech among politicians, scientists and practitioners, as well as about the legal framework of this area. The value of this article is to clarify and propose an apprach to definition of FinTech by combining different approaches in a very original and innovative way.

Keywords: Definition of FinTech, characteristics of FinTech, regulatory arbitrage.

JEL Code: G20, G23, N20.

Paper Type: Research study.

\footnotetext{
${ }^{1}$ University of Latvia, Latvia, rr@ul.lt

${ }^{2}$ University of Piraeus, thalassinos@ersj.eu
} 


\section{Introduction}

For the last decade FinTech companies are emerging and gaining a good market share of the financial services sector. Mobile applications, social networks, machine learning, distributed ledger technology, cloud computing, big data analytics and artificial intelligence increase our access to financial products and services, while raising new risks to financial stability and integrity (Jedrzejowska et al., 2019; Thalassinos and Thalassinos, 2018; Solovjova et al., 2018). The spread of FinTech technologies can be seen to a large extent in the emergence of FinTech hubs - cities where start-ups, talents and funding are gathering. Since FinTech introduction in the US and the UK about 10 years ago, it has spread around the world now. New FinTech hubs are emerging, indicating that the space is far from fully developed, and that there are many new ways in which start-ups and their technologies continue to change financial services.

For centuries, cities have competed to become financial centres; today they are competing to become FinTech hubs. While centres such as London, New York, and Silicon Valley are widely recognised as dominant FinTech hubs, other centers/countries are interested to become if not global, then at least regional hubs of this fast-growing market. For instance, Australia, Switzerland, and China are showing good progress in recognising their financial centers of Sydney, Zurich, and Shanghai, as global market players. In addition, emerging markets, including Brazil, Israel, and Canada, are expected to play a larger role in the global FinTech ecosystem in the future. According to Business Insider report these centers even being in the early stages of development due to supportive regulatory policy could become significant FinTech market players in the near future (Business Insider, 2018).

Also, smaller countries such as Lithuania, Estonia, Latvia, Malta, Belarus, Gibraltar, Luxembourg are competing for the international regional hubs roles. Their success depends on many factors, as access to finance and human resources and the attitude of national regulators, how open and flexible they are etc. Countries that did not have potential to be traditional centers see an opportunity to boost their economies in this new, only in the process of formation, FinTech market. This fast-developing market structure may boost efficiency and competition, at the same time challenging financial stability and integrity (Grima and Thalassinos, 2020; Thalassinos et al., 2015; Rupeika-Apoga et al., 2018).

Differences in the legal environment can lead to regulatory arbitrage, and instead of creating a stable global financial system, tensions arise regarding the deregulation of the legal environment in order to attract or maintain the activities of FinTech in their jurisdictions, so called a "race to the bottom". National authorities/Regulators around the world are trying to balance competing priorities while ensuring market stability. The first problem they face is how to determine which companies respond to FinTech characteristics and need a favourable legal environment, and which ones 
are simple/traditional financial service providers. In this paper we investigate the definition of FinTech provided by leading international organisations and national authorities of main FinTech market players as USA, UK, China, Singapore, Australia, Switzerland and the EU.

The main challenge of determining FinTech is its versatility and the fact that this phenomenon is in an active stage of development. Meanwhile, national authorities must provide the legal basis for this rapidly developing market not tomorrow, but yesterday. A growing number of jurisdictions are working on a legal basis for defining specific forms of FinTech innovation. Many international and regional groups are currently exploring various aspects of FinTech in accordance with their mandates. The regulators from the USA, China, UK mostly work on payment area and lending, such as crowdfunding and peer-to-peer lending. Some supervisors, for instance the USA, Singapore, Japan, Hong Kong, Australia and Canada, have developed FinTech centers/hubs. Many works or already established regulatory sandboxes that provide for temporary easing or updating of regulatory requirements, for instance the UK, the USA, Australia, Switzerland, Singapore, Hong Kong, Malaysia, Thailand, and the United Arab Emirates. Regulatory sandboxes help FinTech companies to test innovative financial products in real life, without going through the complete authorization and licensing process, but for a limited time.

To investigate the definitions of FinTech introduced by international financial organisations and leading economies national legislation we use the document analysis, which is used to analyse the documents as a data source in qualitative research (Bowen, 2009; Wach, Ward and Jacimovic, 2013). Document analysis tries to examine documents giving an interpretation of the nature, objects, subjects and motives indicated in the documentation. In social science studies, this approach promotes an impartial and consistent analysis of written policy.

\section{The Framework of FinTech at International Level}

There have been calls for increased international cooperation and guidance on how to deal with the fast growing FinTech market and several international financial organisations as IMF, WBG, FSB and others took active part in preparing policy agendas (legal framework).

\subsection{International Monetary Fund (IMF) and World Bank Group (WBG)}

In 2018 IMF and WBG launched the Bali FinTech Agenda (BFA), with a primary goal to consider how technological innovation is changing the delivery of financial services with consequences for economic efficiency and growth, financial stability, inclusion and integrity. BFA defines FinTech as "the advances in technology that have the potential to transform the provision of financial services spurring the development of new business models, applications, processes, and products" (IMF, 2018). The BFA is a response to calls from IMF and WBG members to expand 
international cooperation and provide recommendations on creating a favourable global regulatory environment for FinTech. The Agenda has informative nature to support awareness, further training and ongoing work.

The main conclusion of IMF and World Bank Group policy paper "Fintech: the Experience so far" (IMF, 2019) is that while there are important regional and national differences, countries make extensive use of FinTech capabilities to accelerate economic growth and integration, while balancing risks to stability and integrity.

\subsection{Financial Stability Board (FSB)}

The FSB was established in 2009 as a result of G20 meeting and has taken a key role in facilitating the reform of international financial regulation and supervision. The FSB explains FinTech as "technology-enabled innovation in financial services that could result in new business models, applications, processes or products with an associated material effect on the provision of financial services" (Financial Stability Board, 2019). In 2017, the FSB published "Financial Stability Implications from FinTech", classifying FinTech activities which focuses on the services provided, rather than suppliers or technologies used as:

$>$ payments, clearing and settlement;

$>$ deposits, lending and capital raising;

$>$ insurance;

$>$ investment management;

$>$ market support. (The Financial Stability Board, 2017)

This classification originated from the work of the FSB Financial Innovation Network (FIN), which is based on the classification of the World Economic Forum (2015). In 2015 the World Economic Forum published the report "The Future of Financial Services" exploring the transformative potential of new entrants and innovations on business models in financial services. This project offers answers to the question "Which new innovations are most effective and relevant for the financial services industry?" As a result, 11 key clusters of innovations based on how they impact the core functions of financial services were identified (Figure 1).

As can be seen from Figure 1 the WEF approach to define the FinTech is based on financial market functions that meet client needs. Technological solutions and tools are changing, while core clients' needs remain relatively unchanged. The Figure also provides main innovation clusters, focusing on the key trends driving disruption in financial services business model.

According to the FSB research (The Financial Stability Board, 2017), many national authorities have already adopted legislation or are in adopting process to respond to 
FinTech, but the scope and scale of the changes differ significantly, depending on the size and structure of the national financial markets.

Figure 1. FinTech classification by functions and innovation clusters (the authors created based on WEF report (World Economic Forum, 2015)

\begin{tabular}{|c|c|}
\hline Payments & $\begin{array}{l}\text {-Cashless world: Mobile Payments, Streamlined Payments, Integrated } \\
\text { Billing, Next Generation Security } \\
\text {-Emerging Payment Rails: Cryptographic Protocols, P2P Transfers }\end{array}$ \\
\hline Insurance & $\begin{array}{l}\text {-Insurance Disaggregation: Disaggregated Distribution, Sharing Economy, } \\
\text { Self-Driving Cars, 3rd Party Capital } \\
\text { - Connected Insurance: Smarter, cheaper sensors, Internet-of-Things, } \\
\text { Wearables, standardised Platforms }\end{array}$ \\
\hline $\begin{array}{l}\text { Deposits \& } \\
\text { Lending }\end{array}$ & $\begin{array}{l}\text {-Alternative Lending: P2P Lean, Automated Processes, Alternative } \\
\text { Adjudication } \\
\text {-Shifting Customer Preferences: Virtual Banking 2.0, Banking as Platform } \\
\text { (API), Evolution of Mobile Banking }\end{array}$ \\
\hline Capital Raising & -Crowd-funding: Empowered Angel Investors, Alternative Adjudication \\
\hline $\begin{array}{l}\text { Investment } \\
\text { Management }\end{array}$ & $\begin{array}{l}\text {-Empowered Investors: Social Trading, Automated Advice \& Wealth } \\
\text { Management, Retail Algorithmic Trading } \\
\text {-Process Externalisation: Advanced Analytics, Natural Language, Process- } \\
\text { as-a-Service, Capability Sharing }\end{array}$ \\
\hline $\begin{array}{c}\text { Market } \\
\text { Provisioning }\end{array}$ & $\begin{array}{l}\text {-Smarter, Faster Machines: Machine Accessible Data, Artificial } \\
\text { Intelligence /Machine Learning, Big Data } \\
\text { - New Market Platforms: Fixed Income, Funds, Private Equity/VCS, PC } \\
\text { Shares, C \& D Contracts }\end{array}$ \\
\hline
\end{tabular}

\subsection{The Organisation for Economic Co-operation and Development (OECD)}

Also, the OECD has been actively involved in determining the nature of the FinTech phenomenon. In the paper "Financial Markets, Insurance and Private Pensions: Digitalisation and Finance" the OECD attempts to overcome the limitations in the definitions and categories developed so far. It defines FinTech as "innovative applications of digital technology for financial services" (OECD, 2018). By criticising definitions given by the WEF, the US National Economic Council, the FSB, the International Organization of Securities Commissions (IOSCO), the EU and the Hong Kong Monetary Authority (HKMA), stated that "fintech involves not only the application of new digital technologies to financial services but also the development of business models and products which rely on these technologies and more generally on digital platforms and processes"(OECD, 2018). OECD identifies 
new technologies and digital processing in financial services and main financial activities and services (Table 1):

Table 1. Applications of new technologies to financial services (OECD, 2018)

\begin{tabular}{|c|c|c|c|c|c|c|c|c|}
\hline \multirow{2}{*}{$\begin{array}{l}\text { Digital } \\
\text { Technology }\end{array}$} & \multicolumn{8}{|c|}{ Financial Activities and Services } \\
\hline & 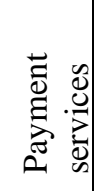 & 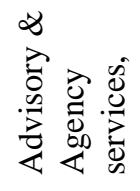 & 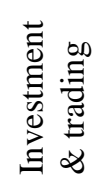 & 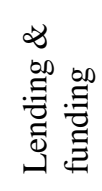 & 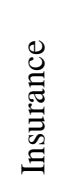 & 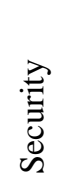 & 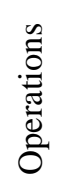 & 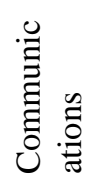 \\
\hline $\begin{array}{l}\text { Distributed Ledger } \\
\text { Technology }\end{array}$ & $\mathbf{X}$ & $\mathbf{X}$ & $\mathbf{X}$ & $\mathbf{X}$ & $\mathbf{X}$ & $\mathbf{X}$ & $\mathbf{X}$ & $\mathbf{X}$ \\
\hline Big Data & & $\mathbf{X}$ & $\mathbf{X}$ & $\mathbf{X}$ & $\mathbf{X}$ & $\mathbf{X}$ & $\mathbf{X}$ & $\mathbf{X}$ \\
\hline $\begin{array}{l}\text { the Internet of } \\
\text { Things }\end{array}$ & & & & & $\mathbf{X}$ & & & $\mathbf{X}$ \\
\hline Cloud Computing & & & & $\mathbf{X}$ & & & $\mathbf{X}$ & \\
\hline $\begin{array}{l}\text { Artificial } \\
\text { Intelligence }\end{array}$ & & $\mathbf{X}$ & $\mathbf{X}$ & & $\mathbf{X}$ & & & $\mathbf{X}$ \\
\hline $\begin{array}{l}\text { Biometric } \\
\text { Technologies }\end{array}$ & & & & & $\mathbf{X}$ & $\mathbf{X}$ & & \\
\hline $\begin{array}{l}\text { Augmented/Virtual } \\
\text { Reality }\end{array}$ & & $\mathbf{X}$ & $\mathbf{X}$ & & & & & $\mathbf{X}$ \\
\hline
\end{tabular}

Source: (OECD, 2018).

Although the OECD paper authors agree with the WEF's approach that core needs of customers remain relatively unchanged, they argue that it is vital how these needs are met. In accordance with the OECD approach, it is not enough to classify FinTech according to the functions of the financial market, but it is also important to identify the technological tools used to provide financial services and associate the services with technological solutions or tools.

\subsection{The International Organization of Securities Commissions (IOSCO)}

In collaboration with G20 and the FSB, IOSCO develops, implements and promotes compliance with internationally recognized standards for securities regulation. The IOSCO defines FinTech as " $a$ variety of innovative business models and emerging technologies that have the potential to transform the financial services industry:"

$>$ Innovative FinTech business models usually offer one or more specific financial products or services automatically using the Internet.

$>$ Emerging technologies such as cognitive computing, machine learning, artificial intelligence, and distributed ledger technologies (DLT) can be used both for new and traditional members, and can also significantly change the financial services industry (International Organisation of Securities Commissions, 2017) 
In the IOSCO Research Report on Financial Technologies (FinTech) are described eight FinTech categories:

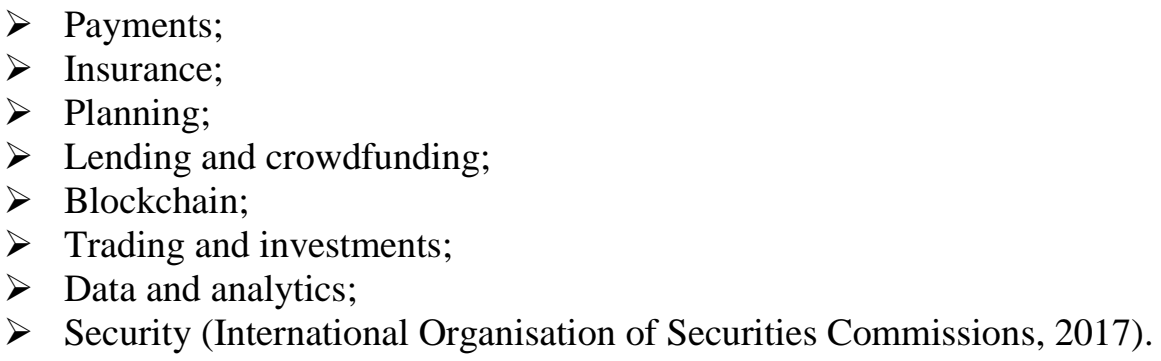

These categories of FinTech meet the basic needs of the client and are based on the functions of financial markets.

\subsection{The Bank for International Settlements (BIS)}

The Basel Committee on Banking Supervision (BCBS) uses the Financial Stability Board's (FSB) definition of FinTech (BIS, 2018). According to BCBS, the regulatory authorities in many countries have not officially defined FinTech, partly because of already available definitions, for instance, such as the FSB's, or that it is too early to offer a definition for a rapidly evolving phenomenon. Those who define FinTech see them as a company that provides innovative services, a business model, or a new-technology start-up in the financial industry. BCBS believes jurisdictions may have to identify specific products and services in order to establish a specific approach for possible regulation.

\section{The National Definitions of FinTech}

\subsection{National Economic Council, White House, USA}

In the USA, there is no specific regulatory framework for FinTech that is subject to any single federal or state regulation. Depending on the activities of the FinTech provided, the company may be subjected to laws and regulations both at the federal and state levels. Fintech will be regulated like any other company if it provides services that are regulated activities, for instance, at the state level consumer lending, money transmission and virtual currency licences, at the federal level consumer lending laws and anti-discrimination laws.

The National Economic Council (NEC) shortly defines FinTech as "innovations in financial technology", but broadly "a wide spectrum of technological innovations which impact a broad range of financial activities, including payments, investment management, capital raising, deposits and lending, insurance, regulatory compliance, and other activities in the financial services space" (National Economic 
Council, 2017). The NEC advises its policy makers and regulators to study best practices abroad, although each practice is not suitable for each jurisdiction, the exchange of ideas and best practices can help harmonize policies and regulations and promote safe innovation around the world.

USA regulation of financial markets is fragmented because of different legal framework in federal and state level, making the creation of one unified sandbox for the country very complicated. The first sandbox was launched in Arizona in 2018, allowing starups, entrepreneurs and even established companies to test their innovative financial products or services in regulatory friendly environment in the state of Arizona. Innovative financial product or service means a financial product or service that includes an innovation (State of Arizona, 2018). The legal explanation of innovation is "with respect to providing a financial product or service or a substantial component of a financial product or service, the use or incorporation of new or emerging technology or the reimagination of uses for existing technology to address a problem, provide a benefit or otherwise offer a product, service, business model or delivery mechanism that is not known by the attorney general to have a comparable widespread offering in this state" (A.R.S. section 41-5601, 2019).

According to Arizona Revised Statutes (A.R.S.) "any person may apply to enter the regulatory sandbox to test an innovation” (A.R.S. section 41-5603, 2019), including as existing Arizona licensees and non-licensed businesses. Although the term FinTech is used on the Arizona Attorney General's homepage, in the context of the FinTech sandbox, the term "FinTech" is not used in the legal document of A.R.S.

In July 2018 U.S. Treasury published the Executive Order 13772 on Core Principles for Regulating the United States Financial System: "A Financial System that creates Economic Opportunities Nonbank Financials, FinTech, and Innovation" on promoting financial innovation. Although, this report is devoted to FinTech and emphasizing that financial services are significantly affected by rapid advances in technology, rapid digitization of the economy and surplus of capital to facilitate innovation, the term FinTech is not explained. In this report FinTech is defined as "financial technology" and FinTech firms as "technology-based" firms (U.S. Department of Treasury, 2018). The Office of the Comptroller of the Currency (OCC) in its document "Considering Charter Applications From Financial Technology Companies" determines FinTech companies as "companies that offer innovative technology-driven products and services" and may be eligible for a national bank charter (The Office of the Comptroller of the Currency, 2018).

At the end of 2018, following the positive example of the UK, the Consumer Financial Protection Bureau (CFPB) has launched a unified regulatory sandbox to promote FinTech development. The Bureau's Office of Innovation issued a "No Action" letter to Upstart Network, a consumer lending platform that leverages artificial intelligence, machine learning, and alternative data sources to price 
consumer credit and automate borrowing. Two sandboxes the Compliance Assistance Sandbox and the Trial Disclosure Sandbox, were created, however, official documents framing the activities of the sandbox (CFPB, 2018a; 2018b) are not using the term "FinTech".

\subsection{The United Kingdom}

In the UK, there is no specific regulatory framework for FinTech enterprises that are subject to UK financial regulation. FinTech will be regulated like any other company if it provides services that are regulated activities, such as "traditional" financial services, for instance, payments or lending, or "alternative" financial services, for instance, crowdfunding. The Financial Conduct Authority (FCA) does not define FinTech other than "financial technology" but provides structure/guidelines for its nature. First, FinTech must be innovative. The FCA claims innovation should has "genuine potential to improve the lives of consumers come to market across all areas of financial services" (Financial Conduct Authority, 2019). In 2019 the FCA defines following areas of financial services providers:

$>$ Banks, building societies and credit unions;

$>$ Claims management companies;

$>$ Consumer credit firms;

$>$ Electronic money and payment institutions;

$>$ Financial advisers;

$>$ Fintech and innovative businesses;

$>$ General insurance and protection;

$>$ Investment managers;

Life insurers and pension providers;

$>$ Mortgage lenders and intermediaries;

$>$ Mutual societies;

$>$ Sole advisers;

$>$ Wealth managers (FCA, 2019).

The improvement is seen whether through products that better suit customers' needs, better access or lower prices. In addition, the FCA states that innovation must be offered by various players, both in terms of the type of company and the people behind the development. In the report about "UK FinTech" Treasury of the UK in collaboration with E\&Y defines FinTech "as high-growth organisations combining innovative business models and technology to enable, enhance and disrupt financial services" (Treasury of the United Kingdom and Ernst \& Young, 2016). This report also identifies key features and emerging areas of FinTech innovation (Table 2).

As can be seen from Table 2, this classification of FinTech is based on the main functions and tools that help to satisfy customer needs. Woolard (2017) (Executive Director of Strategy and Competition at the FCA) said at the Innovate Finance 
Global Summit: "As long as firms are developing innovative products, services and solutions that offer better outcomes for consumers, we're open for business".

Table 2. Innovation characteristics and emerging areas of innovation (Treasury of the United Kingdom and Ernst \& Young, 2016)

\begin{tabular}{|c|c|c|c|c|c|}
\hline & $\begin{array}{l}\text { Banking and } \\
\text { payments }\end{array}$ & $\begin{array}{l}\text { Credit and } \\
\text { lending }\end{array}$ & Insurance & $\begin{array}{l}\text { Retail } \\
\text { investments } \\
\text { and } \\
\text { pensions }\end{array}$ & $\begin{array}{l}\text { Investment } \\
\text { management, } \\
\text { wholesale banking } \\
\text { and capital markets }\end{array}$ \\
\hline 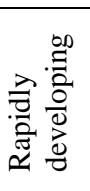 & $\begin{array}{l}\text { Integrated payments } \\
\text { Contactless payments } \\
\text { P2P payments } \\
\text { Money management } \\
\text { tools }\end{array}$ & $\begin{array}{l}\text { P2P } \\
\text { lending } \\
\text { Crowdfun } \\
\text { ding }\end{array}$ & $\begin{array}{l}\text { Telematics } \\
\text { Social } \\
\text { insurance } \\
\text { Wearables }\end{array}$ & \multicolumn{2}{|c|}{$\begin{array}{l}\text { Engaged investing } \\
\text { Visualisation tools } \\
\text { Algorithm advice }\end{array}$} \\
\hline 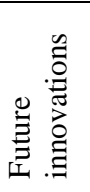 & $\begin{array}{l}\text { Identity management } \\
\text { Financial inclusion } \\
\text { Off-rail payments }\end{array}$ & Open data & $\begin{array}{l}\text { Internet of } \\
\text { things } \\
\text { Autonomou } \\
\text { s vehicles } \\
\text { Blockchain }\end{array}$ & \multicolumn{2}{|c|}{ Smart contracts } \\
\hline
\end{tabular}

Source: (Treasury of the United Kingdom and Ernst \& Young, 2016).

In particular, the United Kingdom has developed an innovative policy strategy to improve the country's competitiveness as a global destination for FinTech. In 2014, the FCA launched the "Project Innovate" with the goal of encouraging innovation in financial services for consumers by supporting innovative enterprises through a range of services. One of the activities is the regulatory sandbox, that allows enterprises to test innovative offers in the market with real consumers. The sandbox is open to authorised firms, unauthorised firms that require authorisation and technology businesses that are looking to deliver innovation in the UK financial services market (FCA, 2019). According to the FCA any company can be seen as FinTech if it interested to deliver innovation that is either regulated business or supports regulated business in the UK financial services market.

In 2019, with the active support of FCA, the Global Financial Innovation Network (GFIN) was launched - an international network of regulators working together to share knowledge and create an environment in which companies can experience cross-border solutions. Of the 12 founding members, GFIN quickly grew to cover a network of 35 organizations.

\subsection{Singapore}

Singapore is the leading FinTech economy in the ASEAN region and is recognized worldwide as a good example of a balance between FinTech support and restrictive rules. As in other countries, also in Singapore, there is no specific legislation framework for FinTech companies. FinTech companies must acquire the right licenses that match their business models, while certain FinTech business models can need multiple licenses based on the service(s) they offer. FinTech firms are 
mainly financial institutions, primarily regulated by the Monetary Authority of Singapore (MAS), but latest trends include the rise of non-financial tech players in FinTech area. One of the MAS tasks is to foster FinTech innovation and make Singapore an international hub for FinTech. Singapore's ambition is to be a Smart Nation, and financial sector is seen as one of its integral parts.

In 2016 MAS lunched the FinTech Regulatory sandbox. According to the guidelines, the applicant can be a financial institution, a FinTech firm, professional services firm partnering with or providing support to such businesses or any interested company that can experiment with innovative financial services in a production environment, but within a clearly defined space and duration. The emphasis is on the use of innovative technologies to provide financial services that are regulated or may be regulated by MAS (MAS, 2016).

Additionally, to complement the current regulatory sandbox in 2019 was launched the sandbox express. The sandbox express, at the first stage, covers the following activities regulated by MAS:

$>$ carrying on business as an insurance broker;

$>$ establishing or operating an organised market;

$>$ remittance business.(MAS, 2019b)

According to the MAS Financial Sector Technology and Innovation (FSTI) Proof of Concept (POC) scheme, that provides funding support for experimentation, development and dissemination of nascent innovative technologies in the financial services sector, two types of companies are eligible for application:

$>$ a financial institution with MAS licence within banking, capital market, financial advisory, insurance and money changing \& remittance businesses;

$>$ a technology or solution provider (artificial intelligence, APIs, blockchain/distributed ledger technology (DLT), cloud, cybersecurity, digital ID \& e-KYC and regtech) with at least one financial institution that is licensed as a partner (MAS, 2019a).

This program supports two activities:

$>$ Projects aimed at developing a new concept for solving industry-wide problems using technologies or business processes;

$>$ Tests aimed at the final response of regulatory uncertainty regarding the risks and benefits of replacing outdated processes with innovative ones.

The Singapore government is actively cooperating at the international level with the authorities and regulatory bodies of other countries, both at the global level, for example, is a member of GFIN, and at the regional level, as a member of the ASEAN Financial Innovation Network (AFIN). 


\subsection{China}

There is no specific legislation framework for FinTech companies in China. In 2015, China's central regulators and industry regulators jointly published Guiding Opinions on Promoting the Healthy Development of Internet Finance (Guiding Opinions). This is China's first comprehensive government Internet-Finance regulation. The concept of Internet Finance was created thanks to the interest of China to promote the "Internet Plus" strategy in all sectors and, thus, has unique Chinese characteristics. Nevertheless, Internet Finance concept is similar to FinTech concept and both can be used to describe new technologies in financial services. In accordance with Guiding Opinions Internet finance consists of:

$>$ Internet payment;

Online lending;

$>$ Equity crowd funding;

$>$ Internet fund sales;

$>$ Online insurance services;

$>$ Internet consumer finance (PBOC, 2015).

Chinese government provides supportive legislation framework for FinTech business, for instance, assisting financial institutions, Internet enterprises and ecommerce enterprises in building innovative Internet platforms, selling financial products and effectively expand the supply chain operations of e-commerce enterprises for the above-mentioned categories. Additionally, Chinese policy includes preferential taxation policies for FinTech business, for instance, the reduction of corporate income tax from $25 \%$ to $15 \%$ or even exemption from it and government grants. In general, Chinese legislative environment was quite flexible comparing with other countries, but disruption and failure in the FinTech sector is pushing government to apply more strict requirements for the industry regulation.

Also new types of FinTech activities have appeared in China, such as the provision of risk management services driven by big data and artificial intelligence, as well as blockchain technology and services business. FinTech business in China is regulated by various administrative measures and guidance, with main supervisors as China Banking and Insurance Regulatory Commission and People's Bank of China.

\subsection{Australia}

Also, in Australia, there is no specific legislation framework for FinTech companies. FinTech companies must acquire the right licenses that match their business models. Broadly it includes financial services and consumer credit licensing, registration and disclosure obligations, consumer law requirements and anti-money laundering and counter-terrorism financing requirements. Generally, a business must obtain an Australian financial services (AFS) licence or Australian credit licence (credit 
licence) from Australian Securities and Investments Commission (ASIC) before it can release a new financial product or service or engage in a credit activity.

According to the Australian Government FinTtech is "all about stimulating technological innovation so that financial markets and systems can become more efficient and consumer focussed" (The Australian Government, 2016). The government in 2015 has launched the National Innovation and Science Agenda (NISA) in order to provide the right political parameters for improving the business and financial environment. In addition, Australian Securities and Investments Commission (ASIC) Innovation Hub provides practical support for FinTech and RegTech businesses. According to the ASIC FinTech are new, innovative businesses. For instance, in Australia's regulatory sandbox, it is possible to test products and services without holding a licence, if the business can rely on ASIC's FinTech licensing exemption, provided under ASIC Corporations (Concept Validation Licensing Exemption) Instrument 2016/1175(ASIC, 2017) and ASIC Credit (Concept Validation Licensing Exemption) Instrument 2016/1176 (ASIC, 2016a).

The FinTech licensing exemption, which facilitates the testing of new FinTech services for providing advice and dealing in or distributing products (other than acting as a product issuer), applies in relation to:

$>$ listed or quoted Australian securities;

D debentures, stocks or bonds issued or proposed to be issued by the Australian Government;

$>$ simple managed investment schemes;

$>$ deposit products;

$>$ some kinds of general insurance products;

$>$ payment products issued by ADIs (an authorised deposit-taking institution - a corporation that is authorised under the Banking Act 1959, including: banks; building societies; and credit unions (ASIC, 2016b).

Anyone is entitled to apply for exemption from a FinTech license to provide financial services if they are not prohibited from providing financial services and are not licensed for Australian Financial Services.

\subsection{Switzerland}

In Switzerland, the legal framework relates to FinTech in accordance with the principle of technology neutrality, applying the same regulation to companies using traditional or innovative technologies. FinTech may be regulated by Swiss Financial Market Supervisory Authority (FINMA) or by self-regulatory organisations, depending on the business activity: 
$>$ company accepting public deposits will be regulated by Banking Act (Die Bundesversammlung der Schweizerischen Eidgenossenschaft, 1934);

$>$ financial intermediary, involving payments, individual portfolio management or lending activities by the Anti-Money Laundering Act (The Federal Assembly of the Swiss Confederation, 1997),

$>$ investment funds management by the Collective Investment Schemes Act (The Federal Assembly of the Swiss Confederation, 2006);

$>$ securities by the Stock Exchange Act (Die Bundesversammlung der Schweizerischen Eidgenossenschaft, 1995);

$>$ insurance by the Insurance Supervision Act (Die Bundesversammlung der Schweizerischen Eidgenossenschaft, 2004);

$>$ other Acts can be applied as Consumer Credit Act or Data Protection Act etc.

In July 2019, the Swiss parliament introduced a new licensing category: FinTech companies, which apply to all business models that accept public deposits of up to CHF 100 million, without actually participating in any lending operations, that is, without investing or paying interest on deposits. Additional requirement is that an institution with a FinTech licence must be a company limited by shares, a corporation with unlimited partners or a limited liability company and must have its registered office and conduct its business activities in Switzerland (FINMA, 2018). The purpose of the new license is to promote innovative business models, so the approach to licensing should not be based on a specific type of static business model. FinTech companies, depending on the structure of the business model, can act as providers of payment services, or as a depository of cryptocurrencies or as crowdlenders etc.

In 2019 the Swiss Government and Parliament continue to work on regulatory sandbox, changing the provisions relating to the sandbox, allowing the non-banks to invest deposits received up to CHF 1 million within the sandbox. But operating in the so-called interest rate differential business is prohibited and remains the privilege of the banks (FINMA, 2019).

\subsection{The European Union}

Until now, the EU, apart from UK, has lagged far behind the leading FinTech economies such as the USA, China, Singapore and Switzerland. Also, according to the Institute for Financial Services Zug FinTech hub ranking in 2018, only Amsterdam (5th place) and Stockholm (7th place) were present in the top 10 global FinTech hubs list (IFZ, 2019). The FinTech report of the European Parliament mentions that more than half of the top 10 FinTech companies are located in the US, China and Israel, and Europe needs rapid innovation to remain competitive (European Parlament, 2017). This is one of the reasons why the EU is trying to be proactive and the European Commission in 2018 adopted the FinTech action plan for the development of a more competitive and innovative financial sector in Europe. 
The main purpose of the plan is to increase supervisory convergence toward technological innovation and prepare the EU financial sector to benefit from new technologies. The definition provided by the European Commission in the FinTech action plan is following: "FinTech - technology-enabled innovation in financial services" (European Commission, 2018). The EC uses the definition provided by international financial organisation, the Financial Stability Board, to explain more detailed what FinTech is, paraphrasing it slightly. "FinTech is a term used to describe technology-enabled innovation in financial services that could result in new business models, applications, processes or products and could have an associated material effect on financial markets and institutions and how financial services are provided" (European Commission, 2018).

According to EU Parliament definition FinTech should be understood "as finance enabled by or provided via new technologies, covering the whole range of financial services, products and infrastructure" (European Parlament, 2017). It also includes InsurTech, and RegTech. The EU institutions are working to create a more futureoriented and innovative-friendly regulatory framework covering digitalization and creating an environment in which FinTech innovative products and solutions can quickly spread across the EU to benefit from huge single European market. The idea underlying this is to simultaneously reduce regulatory requirements for the FinTech sector without compromising financial stability or protecting consumers and investors. For instance, the Payment Services Directive (PSD2), that came in force in 2018, is a step forward more supportive legal environment.

All new EU-legislation should be based on the "innovation principle". The EP emphasizes that, in order to prevent regulatory arbitrage in Member States and legal statuses, legislation and supervision should be based on the following principles:

$>$ Same services and same risks: the same rules should apply, regardless of the type of legal entity concerned or its location in the Union;

$>$ Technology neutrality;

$>$ A risk-based approach, taking into account the proportionality of legislative and supervisory actions to risks and materiality of risks (European Parlament, 2017).

Positive results are already visible, according to the CBI Global FinTech report for the second quarter of 2019, Europe surpasses Asia as the second largest market for FinTech transactions and financing in the first half of the year 2019 (CB Insights, 2019).

\section{The Proposed Approach}

Different definitions of FinTech have been used by international bodies and national authorities. Nevertheless, the most common used FinTech definition during high- 
level international meetings as G-20, IMF and WBG meetings are based on Bali FinTech Agenda paper (2018) and World Economic Forum report (2015).

Analysing the FinTech framework provided by leading international organizations, we come to the conclusion that the general definition of FinTech is quite similar and is based on two conditions. The first condition is the application of new/innovative technologies to financial services. The second condition is the development of new business models, applications, processes or products based on new/innovative technologies. However, how to determine which technologies are new and innovative and leads to new and innovative business models and product development is unclear. All organizations analysed agree that the main attention should be paid to the needs of customers, which are basically unchanged and allow us to classify FinTech based on the services provided in accordance with the functions of the financial markets. Some organizations, such as the IMF, WB, FSB, argue that technological solutions/tools to meet customer needs are secondary, as they are more volatile than core needs of customers. While the OECD proposes to define customer needs and technological solutions on the same, primary, scale.

General national definitions of FinTech are based on framework provided by international organisations; FinTech firms must leverage innovative technology while providing financial services. For instance, the Central Bank of Ireland describes FinTech as "the use of technology to deliver financial services and products to consumers" (Central Bank of Ireland, 2019). This may be in the field of banking, insurance, investment - everything related to finance. In general, this complies with the definition given by WEF, defining FinTech considering the functions of the financial markets that meet the needs of customers.

Nevertheless, there is no specific legislation framework for FinTech companies, except recent FinTech licence in Switzerland. FinTech is generally regarded as any other traditional financial service provider and is subject to the law in accordance with the services provided, and not by type of a company. Mostly FinTech firms are financial companies, that are licenced and regulated according to their business models, or sometimes it can be technology companies that provides financial services.

Moreover, technology neutrality remains the guiding principle, meaning that business operations with similar characteristics are subject to the same regulation regardless of the innovativeness of the technologies used. However, the synthesis of advanced technologies and financial services has led to the emergence of new business models, applications and products that need to be regulated. A new legal framework emerging for crowdfunding investments, crypto assets, block chain information services, initial coin offerings etc. Governors are working on the design of a new financial market architecture. For instance, in Switzerland from 2020 comes in force two major financial market laws; The Financial Services Act (FinSA) 
and the Financial Institutions Act (FinIA), to create uniform competitive conditions for financial intermediaries and improve customer protection.

In general, we can characterize FinTech by focusing on the services, suppliers or technologies used, however, the last word for the client, the needs of customers, and the basic customers' needs based on the functions of financial services remain the same. In our opinion, no specific legislation for FinTech companies is needed, each type of activity provided by a financial or technology company is subject to a specific legislation/regulation with primary focus on services and products provided as payments, insurance, investments etc.

In 2020 we can define the following main activities areas of FinTech:

$>$ Lending (crowdlending, alternative underwriting platforms);

$>$ Distributed ledger technology (crypto/blockchain);

$>$ Personal finance (tools to manage personal finance as accounts and payments);

$>$ Wealth Management (Robo advisor, social trading, investment and wealth management platforms);

> Capital Markets, (sales and trading analysis: big data, machine learning, artificial intelligence);

$>$ Payments (mobile payment, online payment, card developers, payment processing);

Money transfers (international money transfer and tracking software);

$>$ RegTech (risk, regulatory compliance and audit);

$>$ Insurtech (online sales, data analytics for reinsurers);

$>$ Real Estate (mortgage, financing platforms).

The proposed categories are not final and provide only a general description of FinTech covered areas.

\section{References:}

A.R.S. section 41-5601 to 41-5612. 2019. The Arizona Revised Statutes. Retrieved from https://www.azleg.gov/arsDetail/?title=41.

ASIC. 2016a. ASIC Credit ( Concept Validation Licensing Exemption ) Instrument 2016 / 1176, (December), 7.

ASIC. 2016. Testing Fintech Products and Services Without Holding an AFS or Credit Licence.

ASIC. 2017. ASIC Corporations ( Concept Validation Licensing Exemption ) Instrument $2016 / 1175$.

BIS. 2018. Basel Committee on Banking Supervision Consultative Document Sound

Practices: Implications of fintech developments for banks and bank supervisors.

Retrieved from www.bis.org

Bowen, G.A. 2009. Document Analysis as a Qualitative Research Method. Qualitative Research Journal, 9(2), 27-40. https://doi.org/10.3316/qrj0902027. 
Business Insider. 2018. The Global Fintech Landscape.

CB Insights. 2019. Global Fintech Report Q2 2019.

Central bank of Ireland. 2019. Explainer - What is "FinTech" and how is it changing financial products? Retrieved from https://centralbank.ie/consumerhub/explainers/what-is-fintech-and-how-is-it-changing-financial-products.

CFPB. 2018. Policy on the Compliance Assistance Sandbox, $64036 \S$ (2018).

CFPB. 2018. Policy to Encourage Trial Disclosure Programs, $1032 \S(2018)$.

Die Bundesversammlung der Schweizerischen Eidgenossenschaft. 1934. Bundesgesetz über die Banken und Sparkassen (BankG), (November), 1-36. Retrieved from http://www.admin.ch/opc/de/classified-compilation/19340083/index.html.

Die Bundesversammlung der Schweizerischen Eidgenossenschaft. 1995. Bundesgesetz über die Börsen und den Effektenhandel, 1-9.

Die Bundesversammlung der Schweizerischen Eidgenossenschaft. 2004. Bundesgesetz betreffend die Aufsicht über Versicherungsunternehmen, 1-34.

European Commission. 2018. FinTech Action plan: For a more competitive and innovative European financial sector.

European Parlament. 2017. Report on FinTech: the influence of technology on the future of the financial sector (2016/2243(INI)), A8-0176/2017 § (2017). https://doi.org/10.1080/00344897208656356.

FCA. 2019. FCA. Retrieved from https://www.fca.org.uk/firms

Financial Conduct Authority. 2019. The Impact and Effectiveness of Innovate, (April). Retrieved from https://www.fca.org.uk/publication/research/the-impact-andeffectiveness-of-innovate.pdf.

Financial Stability Board. 2019. FinTech and market structure in financial services: Market developments and potential financial stability implications - Financial Stability Board, (February). Retrieved from www.fsb.org/emailalert\%0Ahttp://www.fsb.org/2019/02/fintech-and-market-structurein-financial-services-market-developments-and-potential-financial-stabilityimplications/.

FINMA. 2018. Guidelines for FinTech licence applications pursuant to Article $1 \mathrm{~b}$ of the Banking Act, $41 \S$ (2018).

FINMA. 2019. FinTech licence and sandbox: adjustments to FINMA circulars. Retrieved from https://www.finma.ch/en/news/2019/03/20190315-mm-fintech/.

Grima, S., Thalassinos, I.E. 2020. Financial Derivatives: A Blessing or a Curse? Emerald Publishing Co., London UK, ISBN: 9781789732467. https://books.emeraldinsight.com/page/detail/FinancialDerivatives/?k=9781789732467.

IFZ. 2019. 2018 IFZ Global FinTech Rankings. Retrieved from https://innovation.thomsonreuters.com/en/labs/portfolio/global-fintech-rankings.html.

IMF. 2018. The Bali Fintech Agenda. IMF Policy Paper, (October), 43.

IMF. 2019. FinTech: the Experience so far. IMF Policy Paper, (June), 77.

International Organisation of Securities Commissions. 2017. IOSCO Research Report on Financial Technologies (FinTech). International Organization of Securities

Commissions. Retrieved from https://www.iosco.org/library/pubdocs/pdf/IOSCOPD554.pdf.

Jędrzejowska-Schiffauer, I., Schiffauer, P., Thalassinos, I.E. 2019. EU Regulatory Measures Following the Crises: What Impact on Corporate Governance of Financial Institutions? European Research Studies Journal, 22(3), 432-456.

MAS. 2016. Fintech Regulatory Sandbox Guidelines. Retrieved from 
https://www.mas.gov.sg/-/media/MAS/Smart-Financial-Centre/Sandbox/FinTechRegulatory-Sandbox-Guidelines-

19Feb2018.pdf?la=en\&hash=1F4AA49087F9689249FB8816A11AEAA6CB3DE833.

MAS. 2019a. MAS FSTI Proof-of-Concept Grant. Retrieved from

https://www.mas.gov.sg/development/fintech/mas-fsti-proof-of-concept-grant

MAS. 2019 b. Sandbox Express.

National Economic Council. 2017. A Framework for FinTech.

OECD. 2018. Financial Markets, Insurance and Private Pensions: Digitalisation and Finance.

PBOC. 2015. Guiding Opinions on Promoting the Healthy Development of Internet Finance.

State of Arizona. House Bill 2434. 2018. House of Representatives Fifty-third Legislature

Second Regular Session.

Rupeika-Apoga, R., Zaidi, H.S., Thalassinos, E.Y., Thalassinos, I.E. 2018. Bank Stability:

The Case of Nordic and Non-Nordic Banks in Latvia. International Journal of

Economics and Business Administration, 6(2), 39-55, DOI: 10.35808/ijeba/156.

Thalassinos, I.E., Thalassinos, E.P., Venedictova, B., Yordanov, V. 2015. Currency Board

Arrangement Capital Structure Macro-Financial Diagnostic. SSRN-id2624333.pdf.

Thalassinos, I.E., Thalassinos, E.Y. 2018. Financial Crises and e-Commerce: How Are They Related? Available at SSRN: https://ssrn.com/abstract=3330169

The Australian Government. 2016. Backing Australian FinTech. Retrieved from http://fintech.treasury.gov.au/files/2016/03/Fintech-March-2016-v3.pdf.

The Federal Assembly of the Swiss Confederation. 1997. Federal Act on Combating Money Laundering and Terrorist Financing in the Financial Sector. Retrieved from http://www.admin.ch/ch/e/rs/9/955.0.en.pdf.

The Federal Assembly of the Swiss Confederation. 2006. Federal Act on Collective Investment Schemes, 1-58.

The Financial Stability Board. 2017. Financial Stability Implications from FinTech: Supervisory and Regulatory Issues that Merit Authorities' Attention, (June), 1-65. Retrieved from http://www.fsb.org/wp-content/uploads/R270617.pdf.

The Office of the Comptroller of the Currency. 2018. Comptroller's Licensing Manual Supplement: Considering Charter Applications from Financial Technology Companies.

Treasury of the United Kingdom and Ernst \& Young. 2016. UK FinTech: On the cutting edge. An evaluation of the international FinTech sector, 1-130. Retrieved from https://www.ey.com/Publication/vwLUAssets/EY-UK-FinTech-On-the-cuttingedge/\%24FILE/EY-UK-FinTech-On-the-cutting-edge.pdf.

Solovjova, I., Rupeika-Apoga, R., Romanova, I. 2018. Competitiveness Enhancement of International Financial Centres. European Research Studies Journal, 21(1), 5-17, DOI: $10.35808 / \mathrm{ersj} / 925$.

U.S. Department of Treasury. 2018. A Financial System that Creates Economic Opportunities Nonbank Financials, FinTech, and Innovation.

Wach, E., Ward, R., Jacimovic, R. 2013. Learning about Qualitative Document Analysis.

Woolard, C. 2017. Innovating for the future: the next phase of Project Innovate. Retrieved from https://www.fca.org.uk/news/speeches/innovating-future-next-phase-projectinnovate.

World Economic Forum. 2015. The Future of Financial Services - How disruptive innovations are reshaping the way financial services are structured, provisioned and consumed. Wef, (June), 1-178. 